\title{
Metal contamination of vineyard soils in wet subtropics (southern Brazil)
}

\author{
Nicolai Mirlean ${ }^{\mathrm{a}, *}$, Ari Roisenberg ${ }^{\mathrm{b}}$, Jaqueline O. Chies ${ }^{\mathrm{b}}$ \\ ${ }^{a}$ Fundação Universidade do Rio Grande, Department of Geosciences, Av. Italia - km-08, \\ Campus Carreiros, CEP 96201-900 Rio Grande-RS, Brazil \\ ${ }^{\mathrm{b}}$ Uneversidade Federal do Rio Grande do Sul, Institute of Geosciences, Brazil
}

Received 4 April 2006; received in revised form 16 December 2006; accepted 20 December 2006

Copper-based pesticide use in wet subtropics is environmentally more risky.

\begin{abstract}
The vine-growing areas in Brazil are the dampest in the world. Copper maximum value registered in this study was as much as $3200 \mathrm{mg} \mathrm{kg}^{-1}$, which is several times higher than reported for vineyard soils in temperate climates. Other pesticide-derived metals accumulate in the topsoil layer, surpassing in the old vineyards the background value several times for $\mathrm{Zn}, \mathrm{Pb}, \mathrm{Cr}$ and $\mathrm{Cd}$. Copper is transported to deeper soils' horizons and can potentially contaminate groundwater. The soils from basaltic volcanic rocks reveal the highest values of $\mathrm{Cu}_{\mathrm{extracted}} \mathrm{with} \mathrm{CaCl}{ }_{2}$, demonstrating a high capacity of copper transference into plants. When evaluating the risks of copper's toxic effects in subtropics, the soils from rhyolitic volcanic rocks are more worrisome, as the $\mathrm{Cu}$ extracted with ammonium acetate $1 \mathrm{M}$ surpasses the toxic threshold as much as $4-6$ times.
\end{abstract}

(C) 2007 Elsevier Ltd. All rights reserved.

Keywords: Metals; Vineyards; Wet subtropics; Soil pollution; Groundwater contamination

\section{Introduction}

The use of copper fungicides has led to long-term accumulation of $\mathrm{Cu}$ in vineyard soils (Besnard et al., 2001). Uncontaminated soils present concentrations of $\mathrm{Cu}$ varying between 2 and $40 \mathrm{mg} \mathrm{kg}^{-1}$ (Beus et al., 1976; Adriano, 1986; Weng et al., 2003). The total copper concentrations exceeding $60 \mathrm{mg} \mathrm{kg}^{-1}$ in soil normally require environmental risk assessments (Schramel et al., 2000), and soils in vineyard plots can contain as much as several times this value (Delas, 1963; Leeper, 1978; Prasad et al., 1984; Pietrzak and McPhail, 2004; Vavoulidou et al., 2005). The maximum copper concentration in vineyard soils $\left(1500 \mathrm{mg} \mathrm{kg}^{-1}\right)$ was reported in France, where the copper-based fungicide had been applied

\footnotetext{
* Corresponding author. Tel.: +55 53 32336786; fax: +55 5332336790 .

E-mail address: dgeonmir@furg.br (N. Mirlean).
}

for the first time about 130 years ago (Flores-Veles et al., 1996).

The copper content in vineyard soils is attributed to factors such as frequency of pesticide application and local climatic conditions. Studies from France and Italy demonstrate that vineyard soils in wet regions contain more copper than in dry regions (Brun et al., 1998; Deluisa et al., 1996). The copper contained in topsoil is susceptible both to lateral water erosion of soil phenomena (Ribolzi et al., 2002) and leaching down to deeper horizons (Mirlean et al., 1980).

$\mathrm{Cu}$ accumulated above a threshold in soils can be responsible for the phytotoxic effects which depend on soil properties. The toxicity of $\mathrm{Cu}$ is observed in acid soils and in soils with a low cation exchange capacity (Gupta and Aten, 1993; Brun et al., 2001).

Vineyard soil contamination through other metals usually is studied after long-term compost application (Moolenaar and Beltrami, 1998; Pinamonti et al., 1999). However, the 
$\mathrm{CuSO}_{4}$ used for Bordeaux mixture preparation contains various metals other than copper, and its significant contribution in the metal concentrations of Brazilian grape products has been reported (Mirlean et al., 2005). The effect of copperbased pesticide application on soil contamination by other metals also should be investigated (Merry et al., 1983; Narimanidze and Brückner, 1999).

In Brazil, vine-growing areas are mainly situated in the most southern state, Rio Grande do Sul, where a rather cold winter facilitates grape cultivation. However, because of wet subtropical climate it could be considered as the dampest viticulture area in the world with a mean annual precipitation up to $2000 \mathrm{~mm}$. High humidity and rains demand more often application of copper-based fungicide which definitely contributes to environmental contamination. Today's prosperity in the area of viticulture in Brazil has stimulated the vine-growing, consequently, increasing the area of environmental pollution risk.

The objectives of this study are: (1) to obtain data on the amounts of $\mathrm{Cu}$ built-up and distribution along profiles of different soil types in subtropical vineyards; (2) to quantify the potential $\mathrm{Cu}$ phytoavailability; (3) to obtain data on other metal accumulation due to pesticide impurity in vineyard soils; and (4) to compare the wet subtropical data with data from other climatic zones.

\section{Materials and methods}

\subsection{Study area}

Two vine-growing areas were studied in Rio Grande do Sul State which is the principal wine production region in Brazil. The studied vineyards were selected based on empirical experience as a result of a survey with 15 vineyard owners concerning the main characteristics of their plots, such as, history of winegrowing, soil properties, and the use of fertilizers and copper-based chemicals.

The location of the vineyards is shown in Fig. 1, and brief descriptions of their characteristics are given below. The names of specific locations are not disclosed according to agreements with the owners.

\subsubsection{Bento Goncalves}

Bento Goncalves district is located in a mountainous region in the northern part of the state of Rio Grande do Sul. This region has a humid subtropical climate and two principal soil types: ferrasols (FR) derived from Mesozoic basalts, and podzols (PZ) developed on Mesozoic rhyolites. The selected vineyards were named as FR5, FR40, PZ61, and PZ100, indicating the soil type and vineyard age. The vineyards' sizes varied from 0.8 to 1.4 ha. Copper applications in vineyards varied from 60 to $80 \mathrm{~kg} / \mathrm{ha}$ of copper sulphate per year.

\subsubsection{Ilha dos Marinheiros}

Ilha dos Marinheiros is an island located at the outlet of the Patos Lagoon with the Atlantic Ocean where the vine-growing started about 50 years ago. A number of owners, because of economical reasons, abandoned their plots in the 1980s. Vines are grown in arenosols (AR) from Quaternary eolic sands. The selected vineyards from this region were named as AR45 and AR-20, the last one was planted about 50 years ago and abandoned (pesticide and fertilizer apply discontinued) 20 years ago. The vineyards' sizes were AR45 - 0.8 ha and AR-20 - 0.4 ha. Copper applications in vineyards according to owner information were about $60 \mathrm{~kg} / \mathrm{ha}$ of copper sulphate per year.

\subsubsection{Background}

In Bento Goncalves two sites with FR and PZ soils free of visible anthropogenic impact were selected in native forests. These two sites are situated in the same area and correspond to the background, being named as $\mathrm{FR}_{\mathrm{bg}}$ and $\mathrm{PZ}_{\mathrm{bg}}$. For Ilha dos Marinheiros the background site has been selected in the Regional Nature Reserve Area with AR soils, named as $\mathrm{AR}_{\mathrm{bg}}$.

\subsection{Sampling and preparation of soil and groundwater}

At each vineyard and background site a soil profile was sampled. Soil profiles were sampled at four intervals $0-5 \mathrm{~cm}, 5-25 \mathrm{~cm}, 25-45 \mathrm{~cm}$ and $45-65 \mathrm{~cm}$, using a handle steel soil sampler with $1.0 \mathrm{~m}$ in overall length and $2.5 \mathrm{~cm}$ in diameter. The sampling intervals were selected uniformly for the best comparison of different soils. In AR soils the profile sampling was performed down to groundwater level at a depth of $1.0 \mathrm{~m}$. In each vineyard, apart from the profile samples, three soil samples $(0-5 \mathrm{~cm})$ from seven different places were collected; two samples at the vine lines and one in the middle of the row, between two sampled vine lines (i.e. 21 surface soil samples for each vineyard). In the background sites, soil samples were taken in five replicates. Soil samples were placed and transported in polyethylene bags.

Prior to analysis, all soil samples were air-dried, lightly grounded and sieved through a $2 \mathrm{~mm}$ nylon sieve. FR and PZ soils' analyses were performed using a size fraction smaller than $2000 \mu \mathrm{m}$, and for AR soils the analyzed fraction was smaller than $63 \mu \mathrm{m}$ because of low metal content in the total sample.

Organic matter content and soil $\mathrm{pH}$ were determined in soil samples as described by Porta et al. (1986). The barium chloride method was used to measure cation exchange capacity in soil samples (Hendershot and Duquette, 1986).

For total metal analyses, soil samples, previously pulverized in agate (metal free) mortar, were digested using the $\mathrm{HF} / \mathrm{HClO}_{4} / \mathrm{HNO}_{3}$ method: about $1 \mathrm{~g}$ of the sample was digested with an acid mixture for $12 \mathrm{~h}$ at room temperature, then evaporated in a Teflon vial until the wet salt state, then diluted to $100 \mathrm{ml}$ with distilled water and filtered (Zyrin, 1981).

To evaluate available copper in soil, the French standard extraction methods (NF X 31-120 and NF X 31-121; Afnor, 1994) and methods described by Brun et al. (1998) were used:

1. Calcium chloride extraction: $5 \mathrm{~g}$ of soil was extracted with $50 \mathrm{ml}$ of $\mathrm{CaCl}_{2} 0.01 \mathrm{M}$ for $2 \mathrm{~h}$ at $20^{\circ} \mathrm{C}$ under stirring, prior to being filtered.

2. Ammonium acetate extraction: $10 \mathrm{~g}$ of soil was extracted with $200 \mathrm{ml}$ of $\mathrm{CH}_{3} \mathrm{COONH}_{4} 1 \mathrm{M}$ for $1 \mathrm{~h}$ at $20^{\circ} \mathrm{C}$ under stirring, prior to being filtered.

3. EDTA extraction: $7.5 \mathrm{~g}$ of soil was extracted with $50 \mathrm{ml}$ of $\mathrm{Na}_{2}$-EDTA $0.01 \mathrm{M}+\mathrm{CH}_{3} \mathrm{COONH}_{4} 1 \mathrm{M}$ for $2 \mathrm{~h}$ at $20^{\circ} \mathrm{C}$ under stirring, prior being filtered.

A groundwater sample in Bento Goncalves (FR5-FR40) was taken from the groundwater spring below the vineyards; two samples were pumped (depth of $1.0 \mathrm{~m}$ ) from the soil sampling points in Ilha dos Marinheiros (AR45, AR-20), and one sample from the drilling in the Nature Reserve $\left(\mathrm{AR}_{\mathrm{bg}}\right)$. Samples were placed in $1 \mathrm{~L}$ polypropylene flasks and transported to the laboratory. In the laboratory, water samples were filtered through a $0.45 \mu \mathrm{m}$ membrane, acidified by $\mathrm{HNO}_{3}$ s.p. and stored in a refrigerator $\left(+4{ }^{\circ} \mathrm{C}\right)$ for later analyses.

\subsection{Chemical analysis}

Copper, zinc, and iron from soil samples were analyzed by flame atomic absorption spectrophotometry, while electrothermic atomization mode was used for chromium, nickel, lead, and cadmium analyses in soil samples. The latter method was also used for copper in water samples and extracts (Avanta, 1999). The relative standard deviation maximum value of for three replicate analyses of an individual sample was less than $4 \%$.

The accuracy and precision of the analyses were ensured by sequential digestion and analyses, according to the NRCC-PACS-2 (National Research 


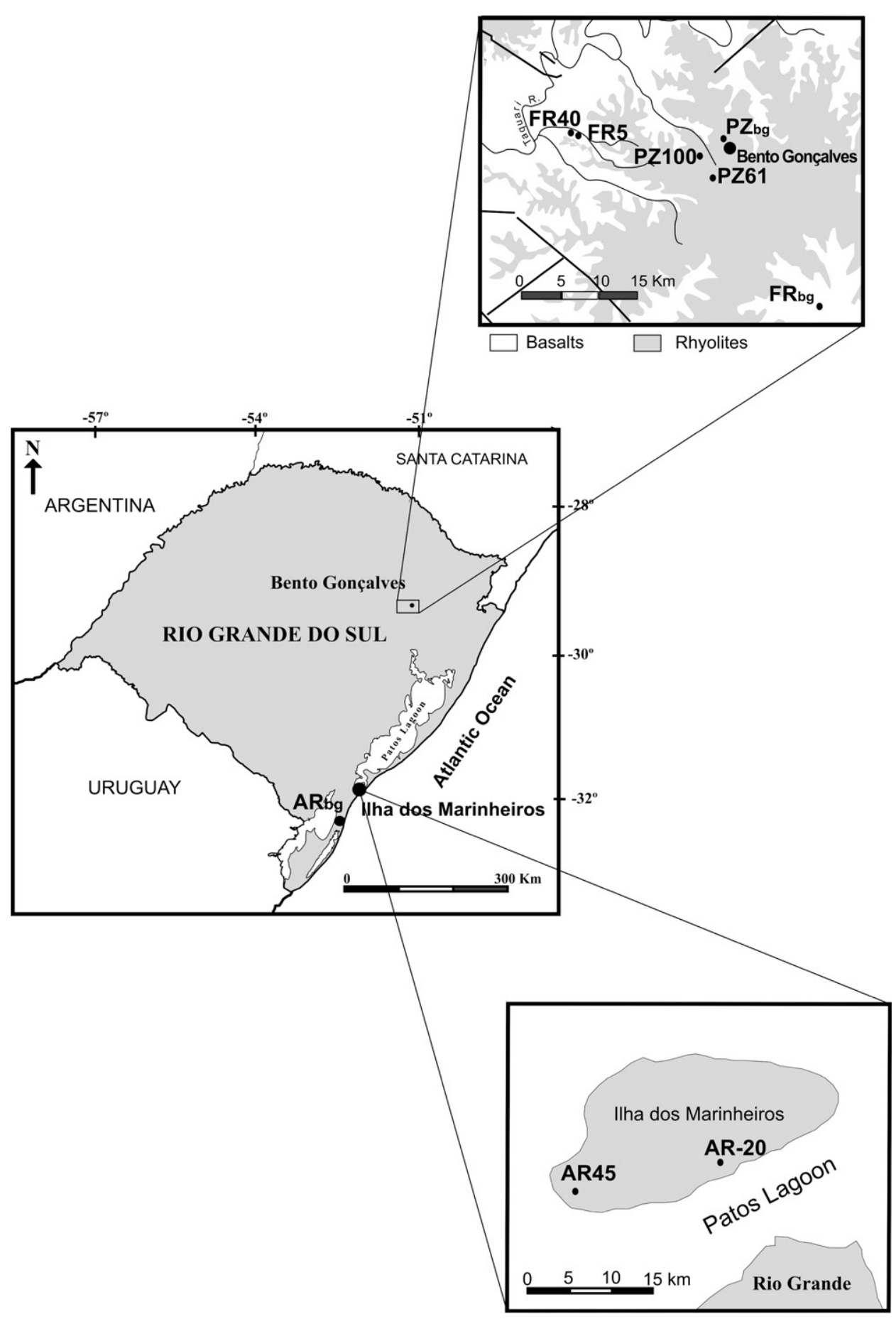

Fig. 1. Location map of the studied areas.

Council of Canada - sediment) Certificate Reference Material (CRM). For all elements except $\mathrm{Cd}$ a recovery was found within the $95 \%$ confidence limits set by the CRM. For cadmium, those values fall outside the limits, but recovery was still within $10 \%$ of the certified value.

Statistical analysis was performed for main components analyzed in 168 soil samples. The software was STATISTICA 6. Differences in $\mathrm{Cu}$ concentration between groups of soil samples were analyzed using one-way ANOVA and Tukey's test at $p<0.05$ significance level. To evaluate the metal vineyard soil enrichment, an enrichment factor $\left(\mathrm{EF}=\mathrm{Me}_{\mathrm{vineyard}} / \mathrm{Me}_{\mathrm{bg}}\right)$ was applied.

\section{Results}

\subsection{Metals in background soils}

Soils from background sites strongly differ in physicochemical properties (Table 1) and analyzed metal contents (Table 2). The $\mathrm{FR}_{\mathrm{bg}}$ soil was about 2.5 times richer in $\mathrm{Cu}$ and 18 and nine times correspondingly richer in $\mathrm{Cr}$ and $\mathrm{Ni}$ 
Table 1

Selected chemical and physical properties of studied soils

\begin{tabular}{|c|c|c|c|c|c|c|}
\hline Soil $(n)$ & Depth $(\mathrm{cm})$ & Clay $0-2 \mu \mathrm{m}(\%)$ & Silt $2-63 \mu \mathrm{m}(\%)$ & Sand $63-2000 \mu \mathrm{m}(\%)$ & $\mathrm{pH} \mathrm{H}_{2} \mathrm{O}(\mathrm{KCl})$ & $\mathrm{C}$ org. $(\%)$ \\
\hline \multicolumn{7}{|l|}{ Background sites } \\
\hline Ferrasol $_{\mathrm{bg}}(3)$ & $0-5$ & 18 & 55 & 27 & $5.8(4.7)$ & 2.2 \\
\hline Podzol $_{\text {bg }}(3)$ & $0-5$ & 30 & 39 & 31 & $4.3(3.7)$ & 1.2 \\
\hline Arenosol $_{\text {bg }}(3)$ & $0-5$ & 0.5 & 4.5 & 95 & $3.9(3.7)$ & 0.4 \\
\hline \multicolumn{7}{|l|}{ Vineyard plots } \\
\hline \multirow[t]{4}{*}{ Ferrasol $5 \mathrm{yr}^{\mathrm{a}}$ (7) } & $0-5$ & 16 & 51 & 33 & $5.9(5.1)$ & 3.1 \\
\hline & $5-25$ & 17 & 53 & 30 & $5.9(5.0)$ & 2.1 \\
\hline & $25-45$ & 16 & 53 & 31 & $6.0(5.0)$ & 1.2 \\
\hline & $45-65$ & 21 & 60 & 19 & $6.2(5.2)$ & 0.9 \\
\hline \multirow[t]{4}{*}{ Ferrasol 40 yr (7) } & $0-5$ & 16 & 54 & 30 & $5.9(5.2)$ & 2.9 \\
\hline & $5-25$ & 15 & 56 & 29 & $6.1(5.3)$ & 2.3 \\
\hline & $25-45$ & 18 & 56 & 26 & $6.1(5.3)$ & 1.4 \\
\hline & $45-65$ & 20 & 55 & 25 & $6.3(5.4)$ & 1.1 \\
\hline \multirow[t]{4}{*}{ Podzol 61 yr (7) } & $0-5$ & 28 & 37 & 35 & $4.5(4.1)$ & 1.6 \\
\hline & $5-25$ & 25 & 36 & 39 & $4.4(3.9)$ & 1.4 \\
\hline & $25-45$ & 29 & 38 & 33 & $5.3(4.2)$ & 0.6 \\
\hline & $45-65$ & 35 & 39 & 26 & $5.1(4.2)$ & 0.3 \\
\hline \multirow[t]{4}{*}{ Podzol 100 yr (7) } & $0-5$ & 33 & 40 & 27 & $4.7(4.3)$ & 1.8 \\
\hline & $5-25$ & 22 & 34 & 34 & $4.2(3.7)$ & 1.7 \\
\hline & $25-45$ & 43 & 45 & 12 & $4.5(3.7)$ & 1.1 \\
\hline & $45-65$ & 45 & 39 & 16 & $5.5(4.7)$ & 0.8 \\
\hline \multirow[t]{4}{*}{ Arenosol 45 yr (7) } & $0-5$ & 1 & 6 & 93 & $4.1(3.9)$ & 0.6 \\
\hline & $5-25$ & 1 & 5 & 94 & $4.1(4.0)$ & 0.2 \\
\hline & $25-45$ & 6 & 10 & 84 & $4.6(4.1)$ & $<0.1$ \\
\hline & $45-65$ & 2 & 5 & 93 & $4.3(4.1)$ & $<0.1$ \\
\hline \multirow[t]{4}{*}{ Arenosol-20 yr (7) } & $0-5$ & 1 & 5 & 94 & $3.9(3.7)$ & 0.3 \\
\hline & $5-25$ & 1 & 5 & 94 & $3.9(3.7)$ & $<0.1$ \\
\hline & $25-45$ & 2 & 5 & 93 & $4.1(3.8)$ & $<0.1$ \\
\hline & $45-65$ & 1 & 6 & 93 & $4.0(3.8)$ & $<0.1$ \\
\hline
\end{tabular}

$n$, Number of individual samples polled to one.

${ }^{\text {a }}$ Vineyard age.

Table 2

Metal concentrations in topsoil, $\mathrm{mg} \mathrm{kg}^{-1}$; (range) average/standard deviation

\begin{tabular}{|c|c|c|c|c|c|c|}
\hline Soil $(n)$ & $\mathrm{Cu}$ & $\mathrm{Zn}$ & $\mathrm{Cr}$ & $\mathrm{Ni}$ & $\mathrm{Pb}$ & $\mathrm{Cd}$ \\
\hline \multicolumn{7}{|l|}{ Background sites } \\
\hline \multirow[t]{2}{*}{ Ferrasol $_{\mathrm{bg}}(5)$} & $(47.4-51.7)$ & $(65.7-88.0)$ & $(58.0-62.0)$ & $(38.5-40.7)$ & $(4.5-5.1)$ & $(00.7-00.8)$ \\
\hline & $49.8 / 2.2$ & $75.0 / 11.6$ & $59.8 / 2.1$ & $39.5 / 1.1$ & $4.8 / 0.3$ & $0.08 / 0.003$ \\
\hline \multirow[t]{2}{*}{ Podzol $_{b g}(5)$} & $(17.1-24.1)$ & $(31.3-54.7)$ & $(2.2-3.9)$ & $(4.4-4.8)$ & $(9.5-12.2)$ & $(0.16-0.17)$ \\
\hline & $20.5 / 3.5$ & $54.6 / 11.9$ & $3.1 / 0.9$ & $4.7 / 0.2$ & $10.7 / 1.4$ & $0.17 / 0.01$ \\
\hline \multirow[t]{2}{*}{ Arenosol bg $_{\text {(5) }}$} & $(3.6-9.5)$ & $(12.3-59.3)$ & $(2.6-3.4)$ & $(3.9-6.7)$ & $(1.6-4.1)$ & $(0.01-0.03)$ \\
\hline & $7.2 / 3.1$ & $31.4 / 13.6$ & $4.5 / 1.9$ & $5.4 / 0.3$ & $2.9 / 1.2$ & $0.02 / 0.01$ \\
\hline \multicolumn{7}{|l|}{ Vineyard plots } \\
\hline \multirow[t]{2}{*}{ Ferrasol $5 \mathrm{yr}^{\mathrm{a}}(21)$} & $(211.4-592.6)$ & (111.4-241.5) & $(54.1-83.0)$ & $(43.9-64.9)$ & $(7.1-15.5)$ & $(0.4-1.1)$ \\
\hline & $353.7 / 118.5$ & $170.1 / 40.0$ & $70.7 / 8.6$ & $54.7 / 6.6$ & $10.7 / 2.7$ & $0.6 / 0.2$ \\
\hline \multirow[t]{2}{*}{ Ferrasol 40 yr (21) } & $(509.2-1504.5)$ & $(100.0-298.2)$ & $(59.4-113.3)$ & $(48.6-66.7)$ & $(7.9-16.3)$ & $(0.3-1.1)$ \\
\hline & $1019.1 / 188.2$ & $201.8 / 51.8$ & $77.9 / 13.9$ & $58.0 / 4.8$ & $11.5 / 2.6$ & $0.7 / 0.2$ \\
\hline \multirow[t]{2}{*}{ Podzol 61 yr (21) } & $(1508.3-2450.1)$ & $(125.6-282.8)$ & $(13.5-26.4)$ & $(6.1-11.5)$ & $(13.6-22.7)$ & $(0.2-1.4)$ \\
\hline & $1838.2 / 228.7$ & $205.2 / 44.0$ & $19.5 / 3.7$ & $8.5 / 1.6$ & $17.4 / 2.5$ & $0.8 / 0.3$ \\
\hline \multirow[t]{2}{*}{ Podzol 100 yr (21) } & $(1213.8-3215.6)$ & $(110.6-369.4)$ & $(19.6-39.2)$ & $(6.3-12.5)$ & $(14.6-46.5)$ & $(0.7-2.8)$ \\
\hline & $2197.6 / 533.7$ & $211.2 / 72.2$ & $26.7 / 5.5$ & $9.0 / 2.1$ & $30.6 / 9.2$ & $1.4 / 0.6$ \\
\hline \multirow[t]{2}{*}{ Arenosol 45 yr $(21)^{b}$} & $(433.7-689.2)$ & $(41.8-61.5)$ & $(3.5-17.7)$ & $(6.2-12.5)$ & $(9.0-16.4)$ & $(0.04-0.15)$ \\
\hline & $536.5 / 75.0$ & $52.1 / 6.4$ & $9.3 / 3.7$ & $8.2 / 1.8$ & $11.9 / 2.1$ & $0.09 / 0.03$ \\
\hline \multirow[t]{2}{*}{ Arenosol-20 yr $(21)^{\mathrm{b}}$} & $(36.5-65.3)$ & $(11.5-21.0)$ & $(5.4-11.6)$ & $(2.4-6.9)$ & $(1.1-2.8)$ & $(0.02-0.04)$ \\
\hline & $50.1 / 8.3$ & $17.5 / 2.8$ & $8.2 / 1.9$ & $4.1 / 1.3$ & $2.0 / 0.6$ & $0.03 / 0.01$ \\
\hline
\end{tabular}

$n$, Number of samples.

a Vineyard age.

b Silt and clay fraction $(<63 \mu \mathrm{m})$. 
than the $\mathrm{PZ}_{\mathrm{bg}}$ soil, which on the contrary was about two times richer in $\mathrm{Pb}$ and $\mathrm{Cd}$ than the $\mathrm{FR}_{\mathrm{bg}}$ soil. The $\mathrm{AR}_{\mathrm{bg}}$ soil contained the lowest concentrations of the majority analyzed metals even in the fine fraction $(<63 \mu \mathrm{m})$ compared to the $\mathrm{FR}_{\mathrm{bg}}$ and $\mathrm{PZ}_{\mathrm{bg}}$ soils.

\subsection{Metals in vineyard topsoil}

Vineyard topsoil in the Bento Goncalves region was strongly polluted by copper. Its total concentration varied between 211 and $1504 \mathrm{mg} \mathrm{kg}^{-1}$ in FR vineyard soil and between 1508 and $3215 \mathrm{mg} \mathrm{kg}^{-1}$ in PZ vineyard soil. In the AR vineyard soil, copper concentration was lower compared to PZ and FR vineyard soils in Bento Goncalves, and varied from 36 to $689 \mathrm{mg} \mathrm{kg}^{-1}$ (fraction $<63 \mu \mathrm{m}$ ).

Vineyard topsoil was enriched by various metals, and generally older the vineyard higher the metal enrichment in the soil of the same type (Table 2). Cadmium demonstrated the highest enrichment factor values (EF) in the oldest vineyard for each soil type (Fig. 2) and chromium demonstrated high EF value in PZ100.

\subsection{Copper distribution in soil profile}

Generally, in vineyard soils on volcanic rocks, copper concentration drastically decreased within the first $10 \mathrm{~cm}$, and then gradually reduced to approximately the background value (Fig. 3a, b). In the oldest vineyard on FR soil, the background level occurred deeper than in the youngest vineyard. In the oldest vineyard on PZ soil, the copper background was not reached even at the maximum depth of sampling, assuming that the copper propagated in deeper horizons.

AR soils have a different copper depth pattern distribution (Fig. 3c) if compared to FR and PZ soils. In operating vineyard AR45, copper concentration decreased in the first $10 \mathrm{~cm}$, then increased in the $25-45 \mathrm{~cm}$ interval, and again decreased in deeper interval of the soil profile, but remained about 30 times higher than the local background.

In the vineyard that was cultivated for 25 years and then abandoned about 20 years ago, copper in the vineyard topsoil was close to background value, but gradually increased with

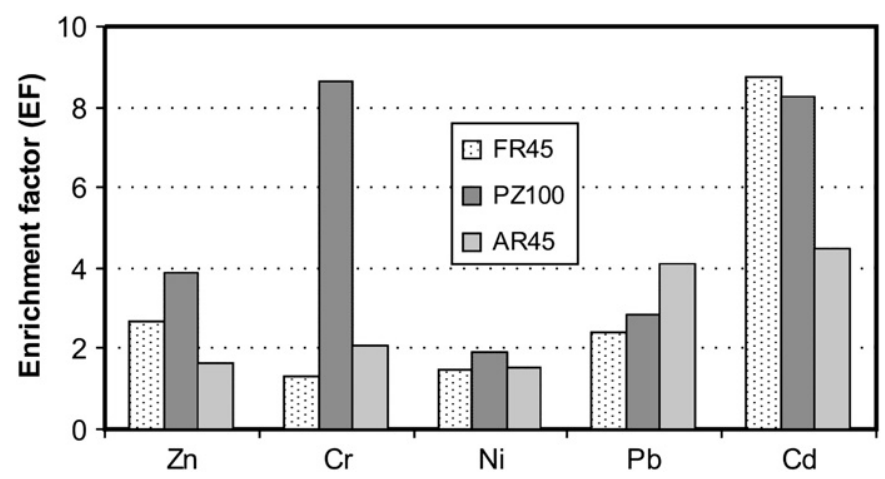

Fig. 2. Vineyard topsoil enrichment by metals. $\mathrm{EF}=\mathrm{Me}_{\text {vineyard }} / \mathrm{Me}_{\text {background }}$. depth reaching its maximum value in horizon $\mathrm{C}$, which surpasses the background value about 20 times.

\subsection{Extractible copper}

Extractible copper values varied depending on soil type and vineyard age. Vineyard FR soils contained the highest concentration of easy extractible copper $\left(\mathrm{CaCl}_{2}\right.$ extraction) (Table 3). Acetate ammonium buffer extracted about 10 times more copper from vineyard PZ soils than from FR vineyard soils. For all vineyard soils, the highest copper values were transferred to the EDTA extraction, and AR soil demonstrated a relative EDTA extractible copper quantity of about $60 \%$ total. It has been observed that the highest copper values were extracted from soils of older vineyards by nearly all types of applied extracts. There was a strong correlation between total copper content and copper transfer to ammonium acetate and EDTA extracts, correspondingly $r=0.91 \quad(p<0.05, n=18)$ and $r=0.98(p<0.05, n=18)$.

\subsection{Copper in groundwater}

In the Bento Gonçalves vineyard plots, copper concentration in groundwater sampled from the spring below FR5FR40 was $3.5 \mu \mathrm{g} \mathrm{L}^{-1}$. In vineyards with AR soils, copper concentration in groundwater was 70.5 and $11.6 \mu \mathrm{g} \mathrm{L}^{-1}$, correspondingly in AR45 and AR-20 plots, versus $2.1 \mu \mathrm{g} \mathrm{L}^{-1}$ in the background site $\mathrm{AR}_{\mathrm{bg}}$.

\section{Discussions}

The data demonstrate strong pollution of vineyard soils by copper. Copper concentrations in the topsoil of Bento Gonçalves vineyard plots significantly surpass the maximum value reported in literature $-1500 \mathrm{mg} \mathrm{kg}^{-1}$ (Flores-Veles et al., 1996). The copper enrichment in different vineyard soil types reflects the period of copper-based pesticide application (Table 2). We consider the climate and application of elevated volumes of fungicide as the circumstantial factor for the high copper contamination in vineyard soil. The average annual precipitation in the studied region is close to $2000 \mathrm{~mm} / \mathrm{yr}$, with 120 rainy days evenly distributed during the year, i.e. during the vegetation period it rains each third day, on average (London Times, 1999). This forces growers to use the Bordeaux mixture more frequently to diminish vine downy mildew attacks. At least $60 \mathrm{~kg} / \mathrm{ha} / \mathrm{yr}$ of copper sulphate is applied, which is 2-4 times more than reported in any other vine-growing area of the world (Mirlean, 1989; Brun et al., 1998; Pietrzak and McPhail, 2004). In exceptionally wet years (El Niňo effect) the pesticide application on vineyards increases. The information presented in Table 4 confirms the relation between data on maximum copper content in vineyard soil and local precipitation, reported from various countries.

Copper distribution between vine lines resembles the same as already described in Pietrzak and McPhail (2004), i.e. copper concentration is higher at the vines than between the vine lines (Fig. 4). However, significant differences $(p<0.05)$ 

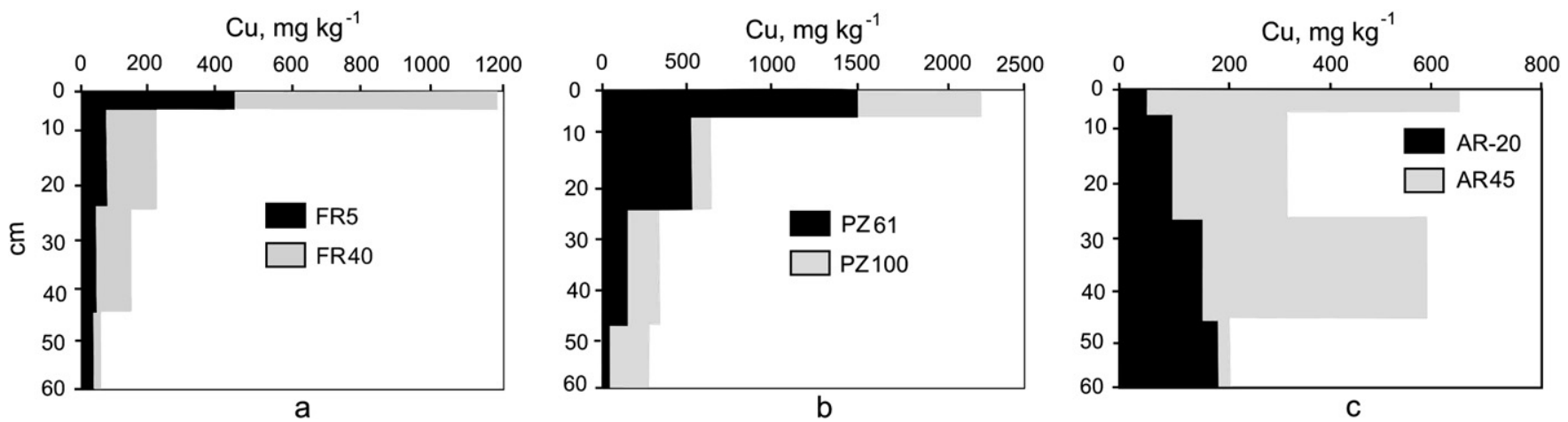

Fig. 3. Copper distribution along vineyard soil profiles: a, FR; b, PZ; c, AR. For AR soil data for fraction $<63 \mu \mathrm{m}$ is plotted.

were only observed for oldest vineyards on soils derived from volcanic rocks (PZ100, PZ61, and FR40). The young vineyard (FR5) and vineyards on arenosols (AR45 and AR-20) displayed insignificant differences $(p>0.05)$. We assume that total copper distribution between vine lines mainly depends on certain technical operations, such as implemented spraying techniques, foliage removing from midway zones or simply foliage and other organic debris redistribution in horizontal directions by winds, machine wheels, people and/or animals.

The copper sulphate actually used for Bordeaux mixture preparation in studied plots contains: $\mathrm{Zn}-1309 \mathrm{mg} \mathrm{kg}^{-1}$, $\mathrm{Pb}-95 \mathrm{mg} \mathrm{kg}^{-1}, \mathrm{Cr}-19 \mathrm{mg} \mathrm{kg}^{-1}, \mathrm{Ni}-10 \mathrm{mg} \mathrm{kg}^{-1}$, and $\mathrm{Cd}-1.4 \mathrm{mg} \mathrm{kg}^{-1}$. No sewage sludge, bark, municipal solid waste, or any other compost, which could contribute to vineyard metal contamination (Pinamonti et al., 1999), were applied in the studied vineyards. Therefore, we consider that copper-based pesticide is the principal source of established soil enrichment by metals. This consideration is supported by the fact that in the studied vineyard topsoil, $\mathrm{Zn}, \mathrm{Pb}$, and $\mathrm{Cd}$ demonstrate significant positive correlation $(r)$ with copper, correspondingly $0.50, \quad 0.81$, and $0.75 \quad(p<0.05$, $n=105$ ), while in the background soil these relations are rather different, insignificant, or negative. The fertilizer application probably adds metal accumulation in soil. However, the vineyard soils in the studied region are fertilized by
$50-100 \mathrm{~kg} / \mathrm{ha}$ of superphosphate once every $3-5$ years, which is about three times less than the quantity of copper sulphate applied during the same period. Besides this, the fertilizers used in the studied plots, on average, contain $\mathrm{Zn}, \mathrm{Pb}$, and $\mathrm{Cd}$ which can reach as much as $135,3.7$, and $4.4 \mathrm{mg} \mathrm{kg}^{-1}$, respectively. So, the fertilizer application probably contributes to $\mathrm{Zn}$ soil contamination about 30 times less and $\mathrm{Pb}$ contamination about 75 times less than Bordeux mixture, but concerning $\mathrm{Cd}$ its contribution is about equal. This last fact could explain a higher $\mathrm{Cd}$ enrichment factor (EF) value in vineyard soils if compared with other metals. High EF of chromium in PZ100 could be explained not only by a very long period of copper fungicide application, but also by a low chromium background in PZ soils.

The difference between precipitation and evaporation from the soil surface in the studied region is about $900 \mathrm{~mm} / \mathrm{yr}$, while in temperate climate vine-growing areas it is significantly lower $(50-350 \mathrm{~mm} / \mathrm{yr})$. So, the large quantity of water that permanently passes through a soil profile creates favorable conditions for metals' leaching. In temperate climates, copper does not normally penetrate below the first $20-30 \mathrm{~cm}$ of the vineyard soil profile (Besnard et al., 2001; Pietrzak and McPhail, 2004) except where copper rich topsoil is displaced downward during deep ploughing (Mirlean, 1989). As the studied soils were not subjected to deep ploughing after the

Table 3

Copper concentration in extracts from background and vineyard topsoil

\begin{tabular}{|c|c|c|c|c|c|c|}
\hline \multirow[t]{2}{*}{ Soil (replicates) } & \multicolumn{2}{|c|}{$\mathrm{CaCl}_{2} 0.01 \mathrm{M}$} & \multicolumn{2}{|c|}{$\mathrm{CH}_{3} \mathrm{COONH}_{4} 1 \mathrm{M}$} & \multicolumn{2}{|c|}{$\mathrm{Na}_{2}$-EDTA $0.01 \mathrm{M}+\mathrm{CH}_{3} \mathrm{COONH}_{4} 1 \mathrm{M}$} \\
\hline & $\mathrm{mg} \mathrm{kg}^{-1}$ & $\%$ of total & $\mathrm{mg} \mathrm{kg}^{-1}$ & $\%$ of total & $\mathrm{mg} \mathrm{kg}^{-1}$ & $\%$ of total \\
\hline \multicolumn{7}{|l|}{ Background sites } \\
\hline Ferrasol $_{\text {bg }}(3)$ & $1.3 \pm 0.06$ & 2.5 & $1.4 \pm 0.06$ & 2.7 & $9.0 \pm 0.45$ & 17.8 \\
\hline Podzol $_{\text {bg }}(3)$ & $0.4 \pm 0.03$ & 2.2 & $0.8 \pm 0.04$ & 4.6 & $5.6 \pm 0.28$ & 28.7 \\
\hline Aerosol $_{\mathrm{bg}}(3)$ & $0.05 \pm 0.03$ & 0.5 & $0.3 \pm 0.02$ & 3.5 & $1.7 \pm 0.07$ & 17.4 \\
\hline \multicolumn{7}{|l|}{ Vineyard plots } \\
\hline Ferrasol $5 \mathrm{yr}^{\mathrm{a}}(3)$ & $5.0 \pm 0.2$ & 0.9 & $38.5 \pm 1.9$ & 6.9 & $312.4 \pm 6.3$ & 34.7 \\
\hline Ferrasol 40 yr (3) & $4.2 \pm 0.2$ & 0.4 & $39.0 \pm 1.9$ & 3.8 & $507.8 \pm 15.2$ & 39.3 \\
\hline Podzol 61 yr (3) & $1.3 \pm 0.05$ & 0.1 & $420.3 \pm 12.3$ & 17.8 & $1193.9 \pm 23.8$ & 50.6 \\
\hline Podzol 100 yr (3) & $2.2 \pm 0.11$ & 0.1 & $606.9 \pm 14.2$ & 28.7 & $1264.8 \pm 31.6$ & 53.1 \\
\hline Arenosol $45 \mathrm{yr}(3)^{\mathrm{b}}$ & $2.5 \pm 0.1$ & 0.4 & $37.7 \pm 1.2$ & 15.7 & $393.5 \pm 8.4$ & 59.5 \\
\hline Aerosol $-20 \mathrm{yr}(3)^{\mathrm{b}}$ & $0.2 \pm 0.06$ & 0.4 & $7.3 \pm 1.0$ & 17.3 & $19.5 \pm 1.2$ & 46.4 \\
\hline
\end{tabular}

${ }^{a}$ Vineyard age.

${ }^{\mathrm{b}}$ Silt and clay fraction $(<63 \mu \mathrm{m})$. 
Table 4

Maximal registered copper concentration in vineyard topsoil and local annual precipitation

\begin{tabular}{llcl}
\hline Country, region & $\begin{array}{l}\text { Precipitation } \\
(\mathrm{mm} / \mathrm{yr})\end{array}$ & $\begin{array}{l}\mathrm{Cu} \\
\left(\mathrm{mg} \mathrm{kg}^{-1}\right)\end{array}$ & Reference \\
\hline Italy, south & 350 & 75 & Deluisa et al. (1996) \\
Greece & 350 & 100 & Vavoulidou et al. (2005) \\
Moldova & 400 & 230 & Mirlean (1989) \\
France, south & 450 & 250 & Brun et al. (1998) \\
Australia & 500 & 250 & Pietrzak and McPhail (2004) \\
Italy, north & 700 & 297 & Deluisa et al. (1996) \\
France, north & 750 & 500 & Drouineau and Mazoyer (1962) \\
France, Bordeaux & 850 & 1500 & Flores-Veles et al. (1996) \\
Brazil, south & $1700-2000$ & 3200 & Current study \\
\hline
\end{tabular}

first vine planting, the copper distribution along the soil profile may be mainly attributed to its leaching. Relatively elevated copper concentration in $25-45 \mathrm{~cm}$ interval in AR45 profile is not caused by ploughing but probably by copper accumulation in clayey streaks which play the role of a barrier for leaching copper (Table 1). In the studied vineyards copper propagates considerably deeper, reaching depths of more than $60 \mathrm{~cm}$. In AR soil copper reaches the groundwater horizon at the depth of about $1.0 \mathrm{~m}$. This deeper propagation of copper in Brazilian vineyards is caused by soil acidity and dense pluvial regime. The present study detected a phenomenon of groundwater contamination by pesticide-derived

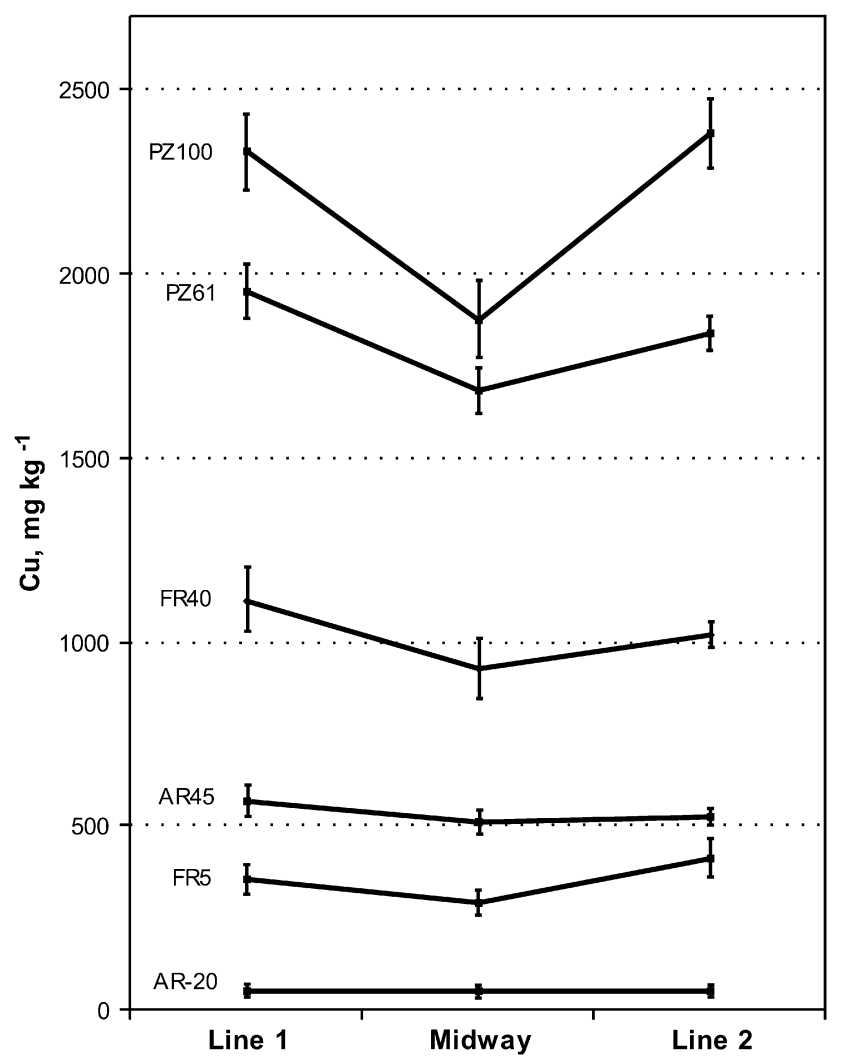

Fig. 4. Distribution of copper concentrations in topsoil $(0-5 \mathrm{~cm})$ between vine lines in studied vineyards (each value is an average of seven individual samples). copper, which could occur when parameters, such as high precipitation, fine granulometry, acidic soil, and shallow aquifer position are simultaneous.

There are various ways of evaluating copper bioavailability and its negative effect on plants through its bioextractability (Brun et al., 1998; Brun et al., 2001; Chaignon et al., 2003). According to Brun et al. (1998), the total $\mathrm{Cu}$ in soil provides little information on copper bioavailability instead the EDTA-extractable $\mathrm{Cu}$ demonstrates the closest relations with total $\mathrm{Cu}$, this extraction method has little importance to predict the availability of $\mathrm{Cu}$ to plants. For soils with neutral to acid $\mathrm{pH}, \mathrm{Cu}$ extracted with $\mathrm{CaCl}_{2}$ significantly correlates with the copper in wild plants, and is a better method to predict plant-available $\mathrm{Cu}$ in vineyard soils. According to Delas (1984), the toxic threshold content for soils with $\mathrm{pH}$ below 6 is generally accepted to be $25 \mathrm{mg} \mathrm{kg}^{-1}$ of $\mathrm{Cu}$ extracted with ammonium acetate $1 \mathrm{M}$ in $\mathrm{AR}$ soils and above $100 \mathrm{mg} \mathrm{kg}^{-1}$ in clayey soils.

The FR soils have the highest values of $\mathrm{Cu}$ extracted with $\mathrm{CaCl}_{2}$ compared to $\mathrm{PZ}$ and $\mathrm{AR}$ soils. The values of $\mathrm{Cu}$ extracted with $\mathrm{CaCl}_{2}$ in FR soils are close to those reported in vineyard soils in the temperate climate of France (Brun et al., 1998), demonstrating a relatively high capacity of copper transfer to plants. When evaluating the risks of copper toxic effects, the PZ soils are more worrisome, as the $\mathrm{Cu}$ extracted with ammonium acetate $1 \mathrm{M}$ in this soil type surpasses the toxic threshold as much as 4-6 times. The AR soils, in spite of their elevated values of extractible copper in the fraction $<63 \mu \mathrm{m}$, could be considered potentially less toxic, as the fine fraction is proportionally less abundant. The greater difference in $\mathrm{Cu}$ extractability between the FR and PZ soils could be explained by the rather different mineralogical composition of the clay fraction. FR soils are richer in hydroxides and oxides of $\mathrm{Fe}$ and $\mathrm{Mn}$, and also contain smectites which have a higher cation sorption capacity than kaolinite, the principal clay mineral in PZ soils (Oliveira et al., 1998). There are no studies available on the toxic effect of high copper concentrations on Brazilian vineyards plants. However, the growers communicated that all their attempts to substitute the vine for other cultures, particularly strawberry, have failed, probably due to soil's strong toxic effect.

\section{Conclusions}

The study showed that copper-based pesticide use in vinegrowing areas of wet subtropical climates lead to the following environmental consequences:

1. vineyard topsoil accumulates up to $3200 \mathrm{mg} \mathrm{kg}^{-1}$ of copper, which is several times higher than in other vine-growing areas throughout the world. The extreme soil contamination by copper is caused by the necessity of a more frequent application of copper-based pesticides in wet climate;

2. pluvious regime and soil acidity favor deeper penetration of copper along the soil profile if compared to other vineyard soils throughout the world. In AR soils, 
pesticide-derived copper reaches the phreatic aquifer and contaminates groundwater;

3. the quantity of copper extracted by ammonium acetate $1 \mathrm{M}$ from soils on rhyolitic volcanic rocks surpasses several times the toxic threshold content for copper in soils;

4. other pesticide-derived metals accumulate in the topsoil, surpassing the background value in oldest vineyards as much as four times for $\mathrm{Zn}$, five times for $\mathrm{Pb}$, and eight times for $\mathrm{Cd}$ and $\mathrm{Cr}$.

Copper-based pesticide use might include a higher environmental risk in wet subtropics than in temperate climate regions.

\section{Acknowledgements}

Funding for this study was provided by the Brazilian National Scientific Council (CNPq).

\section{References}

Adriano, D.C., 1986. Metals in the Terrestrial Environment. Springer-Verlag, Berlin.

Afnor, 1994. Qualité des sols. Méthodes d'analyses. Recueil de normes françaises. Association française de normalisation, Paris.

Avanta, 1999. Atomic Absorption Spectrophotometers. Operational Manual. GBC Scientific Equipment, Australia.

Besnard, E., Chenu, C., Robert, M., 2001. Influence of organic amendments on copper distribution among particle-size and density fractions in Champagne vineyard soils. Environmental Pollution 112, 329-337.

Beus, A.A., Grabovskaia, L.I., Tichonova, N.V., 1976. Environmental Geochemistry. Nedra, Moscow.

Brun, L.A., Maillet, J., Richarte, J., Herrmann, P., Remy, J.C., 1998. Relationships between extractable copper, soil properties and copper uptake by wild plants in vineyard soils. Environmental Pollution 102, 151-161.

Brun, L.A., Maillet, J., Hinsinger, P., Pepin, M., 2001. Evaluation of copper availability to plants in copper-contaminated vineyard soils. Environmental Pollution 111, 293-302.

Chaignon, V., Sanchez-Neira, I., Herrmann, P., Jaillard, B., Hinsinger, P., 2003. Copper bioavailability and extractability as related to chemical properties of contaminated soils from a vine-growing area. Environmental Pollution 123, 229-238.

Delas, J., 1963. La toxicité du cuivre accumulé dans les sols. Agrochimica 7, $258-288$.

Delas, J., 1984. Les toxicités metalliques dans les sols acides. Le Progrès Agricole et Viticole 101, 96-102.

Deluisa, A., Giandon, P., Aichner, M., Bortolami, P., Bruna, L., Lupetti, A., Nardelli, F., Stringari, G., 1996. Copper pollution in Italian vineyard soils. Communications in Soil Science and Plant Analysis 27, 1537-1548.

Drouineau, G., Mazoyer, R., 1962. Contribution à l'étude de la toxicité du cuivre dans tes sols. Ann. Agron. 13, 31-53.

Flores-Veles, L.M., Ducaroir, J., Jaunet, A.M., Robert, M., 1996. Study of the distribution of copper in an acid sandy vineyard soil by three different methods. European Journal of Soil Science 47, 523-532.
Gupta, S.K., Aten, C., 1993. Comparison and evaluation of extraction media and their suitability in a simple model to predict the biological relevance of heavy metal concentrations in contaminated soils. International Journal of Environmental Analytical Chemistry 51, 25-46.

Hendershot, W.H., Duquette, M., 1986. A simple barium chloride method for determining cation exchange capacity and exchangeable cations. Soil Science Society of America Journal 50, 605-608.

Leeper, G.W., 1978. Managing the Heavy Metals on the Land. Marcel Dekker, New York.

London Times, 1999. The Times Atlas of the World: Tenth Comprehensive ed. Random House, London.

Merry, R.H., Tiller, K.G., Alston, A.M., 1983. Accumulation of copper, lead and arsenic in some Australian orchard soils. Australian Journal of Soil Research 21, 549-561.

Mirlean, N., Roisenberg, A., Chies, J.O., 2005. Copper-based fungicide contamination and metal distribution in Brazilian grape products. Bulletin of Environmental Contamination and Toxicology 75, 968-974.

Mirlean, N., Perelman, A.I., Burgelia, N.K., 1980. Anthropogenic copper in Moldavian landscapes. Reports of Academy of Sciences of the USSR 251, 696-699.

Mirlean, N., 1989. Geochemistry of Moldavian Agrolandscapes. Stiintsa, Kishinev (in Russian).

Moolenaar, S.W., Beltrami, P., 1998. Heavy metal balances of an Italian soil as affected by sewage sludge and Bordeaux mixture applications. Journal of Environmental Quality 27, 828-835.

Narimanidze, E., Brückner, H., 1999. Survey on metal contamination of agricultural soils in Georgia. Land Degradation and Development 10, 467-488.

Oliveira, M.T.G., Formoso, M.L.L., Trescases, J.J., Meunier, A., 1998. Clay mineral facies and lateritization in basalts of the southeastern Parana Basin, Brazil. Journal of South American Earth Sciences 11, 365-378.

Pietrzak, U., McPhail, D.C., 2004. Copper accumulation, distribution and fractionation in vineyard soils of Victoria, Australia. Geoderma 122, $151-161$.

Pinamonti, F., Nicolini, G., Dalpiaz, A., Stringari, G., Zorzi, G., 1999. Compost use in viticulture: effect on heavy metal levels in soil and plants. Communications in Soil Science and Plant Analysis 30, 1531-1549.

Porta, J., López-Acevedo, M., Rodriguez, R., 1986. Técnicas y experimentos en edafologia. Colegio Oficial de Ingenieros Agrónomos de Cataluña, Barcelona.

Prasad, B.R., Basavaiah, S., Subba Rao, A., Subba Rao, I.V., 1984. Forms of copper in soils of grape orchards. Journal of the Indian Society of Soil Science 32, 318-322.

Ribolzi, O., Valles, V., Gomez, L., Voltz, M., 2002. Speciation and origin of particulate copper in runoff water from a Mediterranean vineyard catchment. Environmental Pollution 117, 261-271

Schramel, O., Michalke, B., Kettrup, A., 2000. Study of the copper distribution in contaminated soils of hop fields by single and sequential extraction procedures. Science of the Total Environment 263, 11-22.

Vavoulidou, E., Avramides, E.J., Papadopoulos, P., Dimirkou, A., Charoulis, A., Konstantinidou-Doltsinis, S., 2005. Copper content in agricultural soils related to cropping systems in different regions of Greece. Communications in Soil Science and Plant Analysis 36, 759-773.

Weng, H.X., Zhang, X.M., Chen, X.H., Wu, N.Y., 2003. The stability of the relative content ratios of $\mathrm{Cu}, \mathrm{Pb}$ and $\mathrm{Zn}$ in soils and sediments. Environmental Geology 45, 79-85.

Zyrin, V.E., 1981. Trace Metals Analysis in Soil and Plant. Hidrometeoizdat, Moscow (in Russian). 